\title{
Can we grow sperm? A translational perspective on the current animal and human spermatogenesis models
}

\begin{abstract}
Kirk C Lo ${ }^{1,2}$ and Trustin Domes ${ }^{1,2}$
There have been tremendous advances in both the diagnosis and treatment of male factor infertility; however, the mechanisms responsible to recreate spermatogenesis outside of the testicular environment continue to elude andrologists. Having the ability to 'grow' human sperm would be a tremendous advance in reproductive biology with multiple possible clinical applications, such as a treatment option for men with testicular failure and azoospermia of multiple etiologies. To understand the complexities of human spermatogenesis in a research environment, model systems have been designed with the intent to replicate the testicular microenvironment. Currently, there are both in vivo and in vitro model systems. In vivo model systems involve the transplantation of either spermatogonial stem cells or testicular xenographs. In vitro model systems involve the use of pluripotent stem cells and complex coculturing and/or three-dimensional culturing techniques. This review discusses the basic methodologies, possible clinical applications, benefits and limitations of each model system. Although these model systems have greatly improved our understanding of human spermatogenesis, we unfortunately have not been successful in demonstrating complete human spermatogenesis outside of the testicle.
\end{abstract}

Asian Journal of Andrology (2011) 13,677-682; doi:10.1038/aja.2011.88; published online 18 July 2011

Keywords: fertility preservation; spermatogenesis models; spermatogonial stem cells

\section{INTRODUCTION}

Recreating human spermatogenesis outside of its original environment remains the 'Holy Grail' for generations of andrologists. To grow sperm is not only a matter of scientific curiosity, but also a quest for the treatment of male infertility. A well-characterized model for spermatogenesis in humans will have a huge impact on our understanding on the physiological and genetic pathways of male reproduction. Its clinical applications also extend to the study of human reproductive toxicology and preservation of fertility in treated cancer patients.

While significant progress has been made in the laboratory, multiple obstacles remain. Current knowledge on the control of gonadogenesis, spermatogenesis and steroidogenesis are based on the examination of histology, immunohistochemistry, hormonal assays, and phenotypes of single gene or small groups of gene alterations in animal models. Human studies in male reproduction are hindered by the lack of human testicular specimens, which are not as readily available as our animal counterparts, for ethical and practical reasons. In this review, we will examine the existing literature on the experimental models and their limitations in growing sperm to provide a foundation for future investigation and clinical application (Table 1).

\section{IN VIVO SPERM MATURATION STUDIES}

Primitive germ cells or primodial germ cells (PGCs) appear early in the fourth week of fetal development within the yolk sac and soon migrate to the genital ridge to form the sex cords. In the male, the primitive sex cords mature and proliferate to form the testis and rete testis. The gonocytes undergo sexual differentiation to become spermatogonial stem cells (SSCs) in the testis. Germ cells remain relatively quiescent until puberty. At puberty, the spermatogonia, which are located in the basal compartment of the seminiferous epithelium surrounded by the Sertoli cells, undergo a high rate of mitosis and meiosis to eventually differentiate into mature gametes.

Proliferation and differentiation of germ cells are intimately regulated by the microenvironment, or niche, where they reside. This niche is created physically and physiologically by the Sertoli, Leydig and peritubular cells. The Sertoli cells form the blood-testis barrier by lining the basement membrane of the seminiferous tubules and act as the 'nurturing' cells to support spermatogenesis. Under the regulation of follicle-stimulating hormone and testosterone, Sertoli cells secrete numerous factors that are essential for the regulation of spermatogenesis, such as androgen-binding protein, extracellular matrix components, growth factors and steroid hormones. ${ }^{1}$ Leydig cells, under the influence of human chorionic gonadotropin in the fetus and lutenizing hormone otherwise, are responsible for the production of androgens which are important in the regulation of spermatogenesis and for the development and maintenance of male secondary sexual characteristics. Peritubular cells in the testicle are thought to mainly have a contractile function; however, these cells have also been shown to secrete a number of substances that may be important in modulating Sertoli cell function and differentiation. ${ }^{2}$ Hence, the in vivo spermatogenesis models employ the suitable niche for germ

${ }^{1}$ Department of Surgery, University of Toronto, Toronto, Ont., Canada and ${ }^{2}$ Division of Urology, Department of Surgery, Mount Sinai Hospital, Toronto, Ont., Canada Correspondence: Dr KC Lo (klo@mtsinai.on.ca)

Received: 17 December 2010; Revised: 11 March 2011; Accepted: 19 May 2011; Published online: 18 July 2011 
Table 1 Models available for the study of spermatogenesis and male fertility preservation

\begin{tabular}{|c|c|c|}
\hline Model & Benefits/Pros & Limitations/Cons \\
\hline $\begin{array}{l}\text { Spermatogonial stem cell (SSC) } \\
\text { transplantation }\end{array}$ & $\begin{array}{l}\text { 1. Successfully repopulate sterile testes post } \\
\text { gonadotoxic insult with normal germ } \\
\text { cells in various animal models } \\
\text { 2. Potential autologous germ cell stem } \\
\text { cell transplantation in humans could } \\
\text { allow natural conception } \\
\text { 3. The only functional assay to adequately } \\
\text { study SSCs stem cell properties } \\
\text { 4. Research tool for timing spermatogenesis } \\
\text { and germ cell-supporting cell interaction } \\
\text { 5. Preserve germ cells from prized farm animals } \\
\text { and endangered species }\end{array}$ & $\begin{array}{l}\text { 1. Require invasive procedure to transplant } \\
\text { SSCs back into the recipient/patient } \\
\text { 2. Health of offspring has not been } \\
\text { extensively studied } \\
\text { 3. Limited quantity of SSCs available that } \\
\text { can be harvested from patients } \\
\text { 4. Has not been tried in humans due to } \\
\text { risk of relapse of malignancy from } \\
\text { autologous transplantation }\end{array}$ \\
\hline $\begin{array}{r}\text { Testis Xenograph } \\
\text { transplantation }\end{array}$ & $\begin{array}{l}\text { 1. Intact testicular tissue provides optimal } \\
\text { microenvironment for germ cell development } \\
\text { 2. Consistent graft recovery in animal and } \\
\text { human models } \\
\text { 3. Complete spermatogenesis shown in rodents } \\
\text { and higher mammals } \\
\text { 4. Germ cell preservation for prized farm } \\
\text { animals and endangered species } \\
\text { 5. Platform to perform human } \\
\text { spermatogenesis and toxicology studies }\end{array}$ & $\begin{array}{l}\text { 1. Potential contamination of gametes with } \\
\text { xenogenic proteins and/or retroviruses } \\
\text { 2. Applicable to immature testicular tissue only } \\
\text { 3. Unknown genetic/health issues in generated } \\
\text { offspring } \\
\text { 4. Complete spermatogenesis not yet achieved } \\
\text { in human testis xenograft model }\end{array}$ \\
\hline $\begin{array}{l}\text { In-vitro germ cell } \\
\text { maturation }\end{array}$ & $\begin{array}{l}\text { 1. Potential for germ cell expansion in } \\
\text { culture, requiring minimal testicular } \\
\text { tissue for retrieval/banking } \\
\text { 2. No cross contamination from use of animal } \\
\text { surrogates } \\
\text { 3. No invasive transplantation required } \\
\text { in recipients } \\
\text { 4. Potential to derive germ cells from somatic }\end{array}$ & $\begin{array}{l}\text { 1. Requires co-culturing with somatic cells/ } \\
\text { Vero cells and/or growth factors } \\
\text { 2. Potential genetic and epigenetic changes } \\
\text { in the cultured germ cells } \\
\text { 3. Ethical implications regarding stem cell use } \\
\text { 4. Limited supply and availability of } \\
\text { pluripotent stem cells }\end{array}$ \\
\hline
\end{tabular}
cells (?)

cell maturation. Two established in vivo experimental models include SSC transplantation and xenograft of premature testicular tissue transplanted to immunodeficient mouse recipients.

\section{SSC TRANSPLANTATION}

Breakthroughs in SSCs transplantation in the early 1990s inspired a new wave of testicular stem cell research. Ground-breaking research by Brinster and Zimmermann ${ }^{3}$ evaluated the transplantation of normal SSCs into the testes of chemotherapy-treated mice with the goal of restoring spermatogenesis. His technique first isolated SSCs from wild-type (normal) mouse testes. These SSCs were retrogradely injected into a chemotherapy-treated recipient testis (devoid of germ cells) via the efferent duct into the seminiferous tubules. The beauty of this design is that Sertoli and other supporting cells are resilient to most chemotherapies, hence retaining their structure and function. With this scaffold in place, the injected normal SSCs, which have the ability to migrate pass the testisblood barrier formed by the gap junctions between Sertoli cell cytoplasm, can colonize along the basement membrane of the seminiferous tubules. The transplanted SSCs will then proliferate and differentiate to form mature sperm and restore spermatogenesis in the recipient testis. ${ }^{3}$ This theoretical model has successfully restored spermatogenesis with both fresh and cryopreserved mouse SSCs and has been successfully expanded into other animal models, such as rats, ${ }^{4}$ dogs $^{5}$ and goats. ${ }^{6}$ Cross-species transplantation of SSCs has been attempted on the mouse model; however, only rat $^{7,8}$ and hamster ${ }^{9}$ SSCs were capable of complete spermatogenesis in the recipient mouse testis, possibly due to the genetic homology between these species.

The SSC transplantation model has become a vehicle for andrologist to use to gain a better understanding of testicular stem cells and germ cell differentiation. Stem cells are defined by their unique ability to selfrenew, proliferate indefinitely and differentiate into specialized cells/ tissues they are destined to become. SSC transplantation is the only other stem cell 'functional' assay (apart from bone marrow transplantation) that can demonstrate the true 'stemness' (stem cell property) of an isolated cell population. Using this technique, we have learned that the timing of the spermatogenic cycle is regulated by the donor germ cells rather than the recipient supporting cells as demonstrated by the rat to mouse transplantation experiments. ${ }^{7,8}$ The functional characteristics of the SSC and their interaction with the seminiferous tubule and immune cells have also been further explored. ${ }^{10-13}$ Furthermore, by modifying the SSC prior to transplantation, transgenic animals can be generated using this technique. ${ }^{14-17}$

Clinically, there may be potential to apply the SSC transplantation model in humans, especially in the fertility preservation of treated 
pre-pubertal male cancer patients (as outlined in Figure $1^{18}$ ). In postpubertal patients, mature sperm can be easily banked prior to cancer therapies. In pre-pubertal patients, spermatogenic potential is contained within the SSCs. A clinical strategy proposed would be to harvest SSCs from testicular tissue, which could be cryopreserved prior to gonadotoxic cancer therapy. These SSCs could then be injected back into the testicle at a later date if the cancer survivor wishes to have his own genetic children in the future.

Although SSC transplantation in rodents and other higher mammals has been successful, limitations remain that have prohibited the use of this technology in humans. First, the quantity of SSCs that can be harvested from a pre-pubertal testis is very limited, and may not be sufficient to recolonize the donor testis to re-establish fertility. Recent cell culture work by Sadri-Ardekani and colleagues ${ }^{19}$ may ameliorate this situation, as they reported a $>18000$-fold increase in SSCs over 64 days in their post-pubertal human germ line stem cell culture. Although it seems feasible to expand the SSC population prior to transplantation, it remains unknown if pre-pubertal human SSC will react in a similar fashion to the post-pubertal SSC used in the SadriArdekani assay and if clonally expanded SSCs will repopulate the testis in the same fashion as de novo SSC directly from the testis. Second, autologous SSCs transplantation back to a treated cancer patient harbors the theoretical risk of also re-introducing malignant cells. In a rat model, transplantation of testicular cells from leukemic rats led to transmission of leukemia in the recipient rat. ${ }^{19}$ Several strategies are currently been studied to overcome this limitation. Flow cytometry cell sorting and immunomagnetic separation of normal testicular cells from leukemic cells in rodents have yielded variable results. ${ }^{20,21}$ Other techniques for the purification and enrichment of SSCs from the testicular cell population are promising; ${ }^{22-25}$ however, none are yet validated and safe enough for human clinical use.

In summary, the SSC transplantation technique will continue to serve as the primary 'functional' assay in the study of SSC property and specific markers. However, potential use in human fertility preservation and subsequent autologus SSC transplantation back into cancer survivors will need substantial research before it becomes a clinical reality. Future work should include the study of SSCs in vitro expansion with emphasis on the genetic and epigenetic integrity of the resulting SSCs. Combination SSCs purification using more specific markers and extraction of targeted malignant cells from the testicular tissue harvest from cancer patients will also need to be the focus of future studies to guarantee the safety of the recipients. The potential risks to the health of the offspring obtained using this technique in

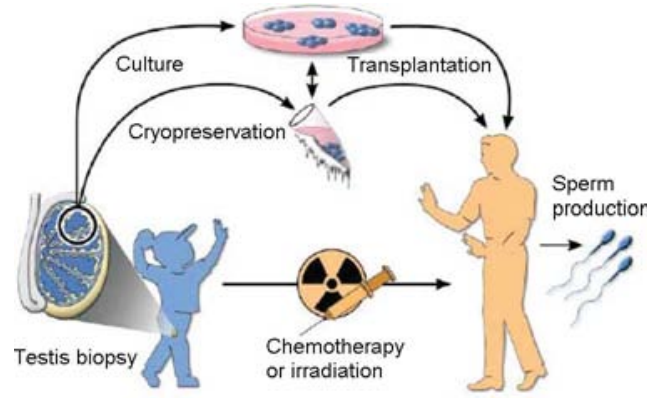

Figure 1 A potential clinical application of spermatogonial stem cell (SSC) transplantation. Prior to gonadotoxic therapy, a biopsy is obtained from a prepubertal testicle to obtain SSCs. SSCs are cryopreserved (and potentially cultured) for future use. At a later date, the cryopreserved SSCs are transplanted back into the patient's testicle for spermatogenetic potential. Figure reproduced with permission from The American Association for the Advancement of Science. ${ }^{18}$ animals will also need to be critically analyzed before any human clinical trial can be conducted.

\section{TESTIS XENOGRAFT TRANSPLANTATION MODEL}

Xenotransplantation is the transplantation of living cells, tissues or organs from one species to another. Grafting of immature (neonatal) donor testis on an immunodeficient recipient mouse can lead to complete spermatogenesis and production of offspring using the mature sperm obtained from the graft (Figure 2). Successful xenografts of fresh and cryopreserved testicular tissue have been reported in a variety of species, including: mouse, ${ }^{26,27}$ hamster, ${ }^{28}$ rabbit, ${ }^{29}$ pig, ${ }^{30}$ goat ${ }^{26}$ sheep, ${ }^{26,31}$ cattle, ${ }^{32,33}$ cat, ${ }^{34}$ horse ${ }^{35}$ and nonhuman primates. ${ }^{36}$ Although the risk of retroviral genetic contamination does exist using this xenograft model, consistent graft recovery and complete spermatogenesis have made this model a valuable tool for animal reproductive and toxicology studies.

The study of a human immature testis xenograft model is limited primarily due to the lack of donor tissues. Xenografting human adult testicular tissue from biopsies obtained from infertile patients unfortunately demonstrated poor survival and failure to support spermatogenesis when grafted into immunodeficient mouse recipients (severe combined immunodeficiency and $\mathrm{Nu} / \mathrm{Nu}) .{ }^{37}$ However, if spermatogenesis was suppressed in the human prior to the creation of the xenograft, better survival of the graft was observed. ${ }^{37}$ This finding seen with human testis xenografts is similarly seen in animal studies where xenografts made from immature testis tissue had better survival and accelerated maturation once transplanted. ${ }^{36}$ For still unknown reasons, mature testis tissue grafts do not support germ cell differentiation as well as immature testis tissue grafts in xenograft models. ${ }^{38}$

To further demonstrate this finding, $\mathrm{Yu}$ and colleagues ${ }^{39}$ transplanted fetal (20-26 weeks) human testicular tissue subcutaneously onto an immunodeficient nude mouse and demonstrated that the xenograft could survive for more than 135 days. These fetal grafts did extremely well; with increased graft weight, Sertoli cell differentiation and germ cell migration were demonstrated over time. Similarly, Sato et al..$^{40}$ transplanted human testicular tissue from a 3-month-old patient to an immunodeficient nude mouse and reported progression of germ cell differentiation from the spermatogonia stage to pachytene spermatocyte formation. As well, Wyns and colleagues ${ }^{41}$ transplanted testicular tissue harvested from five pre-pubertal cancer patients aged 7-14 years prior to chemotherapy into the scrotums of nude mice and

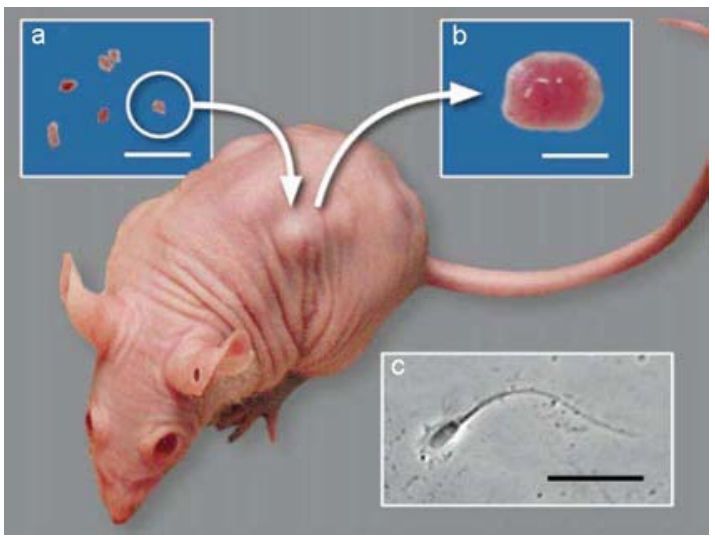

Figure 2 Testis xenograph transplantation model: (a) mammalian neonatal testicular tissue is harvested and transplanted into a nude mouse; (b) the testicular xenograph undergoes growth; (c) mature sperm can be obtained from the xenograph. Figure reproduced with permission from Nature Publishing Group. ${ }^{26}$ 
showed that the xenograft survived greater than 6 months. These xenografts produced numerous pre-meiotic spermatocytes, a few spermatocytes at the pachytene stage and spermatid-like cells, but complete regeneration of normal spermatogenesis with mature sperm cells was not observed. Our laboratory has also recently reported the long-term survival and differentiation of human fetal testes in a xenotransplantation model. ${ }^{42}$ In our study, human fetal testes at gestational age of 9-12 weeks were subcutaneously grafted onto immunodeficient Ncr nude mice. We showed good survival $(>80 \%)$ with minimal inflammatory reaction in the grafted human fetal testis at 24 and 32 weeks post-transplantation. Increased seminiferous tubular size and lumen formation were observed with a corresponding increase in Sertoli and Leydig cell populations. Patterns of gonocyte migration to the basement membrane to become spermatogonia were also observed after 24 weeks. We examined 'host' factors and found no significant difference using castrated or non-castrated recipient mice.

Human xenograft models have shown promising results, but limitations remain. The long-term survival of testicular tissue, the differentiation of gonocytes, the increased germ cell number and Sertoli cell maturation have been remarkable, but demonstrating complete spermatogenesis in a human fetal xenograft model has not been realized. Future research should include the characterization of the xenograft testis with regard to the transition of fetal testicular cells to adult cells. The timing and pattern of specific gene expressions in these supporting cells may lead to clues on factors required for germ cell maturation. The influence of gonadotropins and various growth factors on both germ cell and supporting cells at various stages of testicular development can also be studied using this model.

Clinically, the risk of contamination of germ line cells with that of foreign species will likely prohibit the clinical use of gametes derived from this model for humans. However, the major advantage of this in vivo model is the potential for human reproductive toxicology studies. Currently, the reproductive effect and toxicity of novel pharmaceuticals and chemicals are tested on healthy volunteers. This process is expensive and carries an inherent risk to the subjects. A safer and more efficient pre-clinical platform to study toxicology in humans may involve utilizing a xenografted testis model. Since current models still do not support complete spermatogenesis using human testis, much work is still required.

\section{IN VITRO GERM CELL MATURATION STUDIES}

While the in vivo spermatogenesis models hold great potential in elucidating the mechanisms regulating spermatogenesis, their clinical application in patient care is currently limited. Therefore, an in vitro model is essential to further develop this technology for clinical use.

Simple testicular tissue culture has been attempted and maintained in a variety of species; ${ }^{43-45}$ however, gonocyte development and progression in these models arrests at meiosis. Supporting cells and the microenvironment of the testicle are critical to spermatogenesis, and the challenge of creating an in vitro testicular model has been trying to replicate this in order to successfully grow sperm.

Novel conventional and three-dimensional culture systems have been developed to foster the maturation of sperm (see review by Stukenborg et al. ${ }^{46}$ ). Using a three-dimensional culture system to spatially arrange germ cells, Stukenborg and colleague showed that by coculturing pre-meiotic germ cells with somatic testicular tissue from mice in the presence of gonadotropin, complete maturation of germ cells into morphologically normal spermatozoa can be accomplished. Their in vitro design has nicely recreated the testicular microenvironment by enabling the important germ cell-germ cell contacts necessary for differentiation. This system also provides a platform to further study what optimal components are required to achieve in vitro spermatogenesis, such as media conditions, culture temperatures, gonadotropin/hormone concentrations and the fraction of nongonadal cells required.

More recently, Sato and colleagues ${ }^{47}$ reported successful production of functional sperm in cultured neonatal mouse testes by modifying their tissue culture media. Using a standard gas-liquid interphase method, small fragments of neonatal mouse testis, containing gonocytes or primitive spermatogonia, were placed on an agarose gel and incubated in a modified serum free media. The authors hypothesized that culture media with fetal bovine serum may contain factors that suppress the progress of spermatogenesis. In a serum-free environment, they observed mature spermatozoa after 27-45 days of in vitro culture. The fertilization function of the derived spermatozoa was proven with production of offspring via intracytoplasmic sperm injection of oocytes. This organ-culture system serves as another platform for the study of spermatogenesis, and further refinements are required for testing on other mammalian species.

Currently, there is a paucity of literature addressing in vitro germ cell maturation in humans. Coculturing techniques using Vero cells have proven to be beneficial in the maturation of spermatocytes and spermatids in humans. Vero cells are an immortalized cell line derived from kidney epithelial cells of the green monkey that are used in coculture because they are easy to grow, are embryologically similar to genital epithelial cells and remove toxic compounds from culture medium and act as 'feeder' cells by contributing trophic growth factors. ${ }^{48}$ Cremades and colleagues ${ }^{49}$ cocultured testicular biopsy samples from azoospermic men with Vero cells and reported in vitro maturation of round spermatids to elongated spermatids and mature sperm. However, modern experience with microsurgical testicular sperm extraction has shown that sperm is present in more than $50 \%$ of men with non-obstructive azoospermia. ${ }^{50}$ Therefore, the findings from Cremades' in vitro study may not represent true maturation of spermatids but instead a heterogenous germ cell presence in the biopsied tissue that was later cultured. Control samples that did not involve coculturing would have improved Cremades' study design. Despite this, Tanaka and colleagues ${ }^{51}$ have shown that a single human primary spermatocyte can undergo meiosis and differentiate into round spermatids when cocultured with Vero cells. However, maturation did not continue onto mature sperm in this study. The strengths of Tanaka's study was their use of both Giemsa staining and fluorescent in situ hybridization analysis to confirm the haploid and DNA quantity status of the spermatids and the use of a non-cocultured control group that definitively showed that there was a significant improvement noted with coculturing. Although coculturing with Vero cells is appealing in the laboratory setting, there are concerns using Vero cells in clinical applications due to the theoretical transmission of infectious agents and induction of tumorigenesis. ${ }^{51}$

Further research efforts are required to reveal the applicability of in vitro culture technique for human germ cells. In regard to culture design, three-dimensional culturing has not been attempted with human testicular tissue at this point. As well, further research is required to develop an efficient specially supplemented cell-free cell culture media to promote germ cell development, as there are theoretical concerns regarding the use of Vero cells in human clinical applications. We know that spermatogenesis is modulated by Sertoli cells and more research is required to determine how Sertoli cells modulate germ cell development in the attempt to recreate this process in vitro. In humans, it takes approximately 32 days for a primary spermatocyte 
to complete two meiotic divisions to produce a round spermatid; ${ }^{52}$ however, this process is completed in only $2-5$ days in vitro. The reasons and consequences of this difference have yet to be determined.

Further study is required to determine the viability, functionality, developmental potential and genetic integrity of the germ cells produced in vitro before they could be used in clinical applications.

\section{FROM EMBRYONIC STEM CELLS TO GERM CELLS}

Pluripotent stem cells, such as embryonic stem cells (ESCs) derived from the inner cell mass of a blastocyte, retain the property of selfrenewal and the ability to differentiate into cells and tissues from all three germ layers. Success in the in vitro differentiation of mouse and human ESCs to germ cells has aroused our curiosity in growing sperm from these pluripotent cells. The derivation of germ cells from pluripotent stem cells in vitro could provide an invaluable model system to study both the genetic and epigenetic programming of germ cell development.

Toyooka and colleagues ${ }^{53}$ have reported finding mature germ cells from their cultured ESCs injected into a mouse testis. In a landmark paper, Geijsen et al. ${ }^{54}$ reported the derivation of mouse PGCs by adding retinoic acid to an ESC culture media. The primordial germ cells retain their self renewal properties and further differentiate into haploid male gametes. ${ }^{54}$ The function of these germ cells was eloquently confirmed when intracytoplasmically injected into oocytes, which restored a somatic diploid chromosomal complement with blastocyst formation in $20 \%$. To investigate this process further, Nayernia and his group ${ }^{55}$ in 2006 reported the generation of offspring mice from male gametes derived from in vitro-differentiated ESCs.

In vitro studies in human embryonic stem cells (hESCs) have displayed a similar developmental capacity to generate PGCs as the murine ESCs. hESCs have the potential to spontaneously differentiate to germ cells based on the identification of specific germ cell surface markers and the genetic profile of the cultured cells. ${ }^{56,57}$ However, these phenotypes represented a small proportion of the total cell population at only approximately $0.1 \%$. Growth factors such as bone morphogenetic protein and others play a critical role in inducing germ cell differentiation from hESCs. ${ }^{58-61}$ To date, in vitro models using hESCs have produced post-meiotic spermatids, ${ }^{62}$ but complete spermatogenesis with mature sperm has yet to be reported.

The future of hESC research has become controversial due to the ethics and availability of pluripotent cells. The availability of hESC and embryonic germ cells is dependent on tissue from an excess human embryo and an aborted fetus, respectively. ${ }^{63}$ To circumvent this contentious issue, induced pluripotent stem cells (iPSC) have been developed by activating the pluripotency transgenes such as Yamanaka factors (Oct3/4, Sox2, Klf4 and c-Myc) in adult somatic cells to express embryonic stem cell-like properties. ${ }^{64}$ Many strategies including both viral transfection and non-viral delivery of the reprogramming factor transgenes have been established to provide a source of pluripotent cells from adult tissues. ${ }^{64,65}$ Detailed historical and current methods of nuclear reprogramming of adult cells to pluripotent state can be found in an excellent review by Yamanaka and Blau. ${ }^{66}$ Human iPSC can be obtained using the same approaches, ${ }^{67,68}$ and reprogrammed human iPSCs apparently display similar potential to hESCs in their developmental capacity to generate PGCs. ${ }^{69}$ These investigations are still preliminary, and the impact of this new discovery in human reproductive studies remains to be seen. However, the genetic and epigenetic defects resulted in the derivation of iPSCs, which has raised the question of safety and their eventual use in the clinical setting. A series of recent articles suggest that iPSCs display more abnormalities than do ESCs and fibroblasts. Chromosomal abnormalities seem to appear earlier in iPSCs cultures, ${ }^{70}$ and higher frequency of mutations and greater number of novel copy number variants are also present in iPSCs. ${ }^{70,71}$ Aberrant DNA methylation and retention of epigenetic markers from the cell of origin also suggest significant reprogramming variability in human iPSCs. ${ }^{72}$ As it stands, the lack of genetic stability in iPSCs precludes their use in clinical applications in humans until further research defines the effect of this recent finding.

\section{CONCLUSION}

Successes of both in vivo and in vitro germ cell maturation animal studies have given hope that one day we will be able to grow human sperm as well. SSC transplantation and testis xenograft models have led to complete spermatogenesis in non-primate animals. These in vivo experiments have significant limitations in humans, which have prevented their application clinically thus far. In vitro culturing and maturation of germ cells has been challenging. There is significant promise with embryonic stem cell and primordial germ cell research, but due to ethical and experimental limitations, this research has yet to result in a clinically useful approach to the treatment of male infertility. Clearly, more basic, translational and clinical research is required before in vivo or in vitro maturation of germ cells can be applied for human clinical use.

\section{COMPETING FINANCIAL INTERESTS}

The authors declare no competing financial interests.

1 Mruk DD, Cheng CY. Sertoli-Sertoli and Sertoli-germ cell interactions and their significance in germ cell movement in the seminiferous epithelium during spermatogenesis. Endocr Rev 2004; 25: 747-806.

2 Cigorraga SB, Chemes H, Pellizzari E. Steroidogenic and morphogenic characteristics of human peritubular cells in culture. Biol Reprod 1994; 51: 1193-205.

3 Brinster RL, Zimmermann JW. Spermatogenesis following male germ-cell transplantation. Proc Natl Acad Sci USA 1994; 91: 11298-302.

4 Zhang Z, Renfree MB, Short RV. Successful intra- and interspecific male germ cell transplantation in the rat. Biol Reprod 2003; 68: 961-7.

5 Kim Y, Turner D, Nelson J, Dobrinski I, McEntee M, et al. Production of donor-derived sperm after spermatogonial stem cell transplantation in the dog. Reproduction 2008; 136: 823-31.

6 Honaramooz A, Behboodi E, Blash S, Megee SO, Dobrinski I. Germ cell transplantation in goats. Mol Reprod Dev 2003; 64: 422-8.

7 Clouthier DE, Avarbock MR, Maika SD, Hammer RE, Brinster RL. Rat spermatogenesis in mouse testis. Nature 1996; 381: 418-21.

8 Ogawa T, Arechaga JM, Avarbock MR, Brinster RL. Transplantation of testis germinal cells into mouse seminiferous tubules. Int J Dev Biol 1997; 41: 111-22.

9 Ogawa T, Dobrinski I, Avarbock MR, Brinster RL. Xenogeneic spermatogenesis following transplantation of hamster germ cells to mouse testes. Biol Reprod 1999; 60: 515-21.

10 Parreira GG, Ogawa T, Avarbock MR, Franca LR, Brinster RL et al. Development of germ cell transplants in mice. Biol Reprod 1998; 59: 1360-70.

11 Nagano M, Avarbock MR, Brinster RL. Pattern and kinetics of mouse donor spermatogonial stem cell colonization in recipient testes. Biol Reprod 1999; 60 1429-36.

12 Kubota H, Avarbock MR, Brinster RL. Spermatogonial stem cells share some, but not all, phenotypic and functional characteristics with other stem cells. Proc Nat/ Acad Sci USA 2003; 100: 6487-92.

13 Hamra FK, Chapman KM, Nguyen DM, Williams-Stephens AA, Hammer RE et al. Self renewal, expansion, and transfection of rat spermatogonial stem cells in culture. Proc Natl Acad Sci USA 2005; 102: 17430-5.

14 Nagano M, Brinster CJ, Orwig KE, Ryu BY, Avarbock MR et al. Transgenic mice produced by retroviral transduction of male germ-line stem cells. Proc Natl Acad Sci USA 2001; 98: 13090-5.

15 Kanatsu-Shinohara M, Inoue K, Miki H, Ogonuki N, Takehashi M et al. Clonal origin of germ cell colonies after spermatogonial transplantation in mice. Biol Reprod 2006; 75: 68-74.

16 Ryu BY, Orwig KE, Oatley JM, Lin CC, Chang LJ et al. Efficient generation of transgenic rats through the male germline using lentiviral transduction and transplantation of spermatogonial stem cells. J Androl 2007; 28: 353-60. 
17 Honaramooz A, Megee S, Zeng W, Destrempes M, Overton S et al. Adeno-associated virus (AAV)-mediated transduction of male germ line stem cells results in transgene transmission after germ cell transplantation. FASEB J 2008; 22: 374-82.

18 Brinster RL. Male germline stem cells: from mice to men. Science 2007; 316: 404-5.

19 Sadri-Ardekani H, Mizrak SC, van Daalen SK, Korver CM, Roepers-Gajadien HL et al. Propagation of human spermatogonial stem cells in vitro. JAMA 2009; 302: 2127-34.

20 Fujita K, Ohta $\mathrm{H}$, Tsujimura A, Takao T, Miyagawa $\mathrm{Y}$ et al. Transplantation of spermatogonial stem cells isolated from leukemic mice restores fertility without inducing leukemia. J Clin Invest 2005; 115: 1855-61.

21 Hou M, Andersson M, Zheng C, Sundblad A, Soder 0 et al. Immunomagnetic separation of normal rat testicular cells from Roser's T-cell leukaemia cells is ineffective. Int J Androl 2009; 32: 66-73.

22 Shinohara T, Orwig KE, Avarbock MR, Brinster RL. Spermatogonial stem cell enrichment by multiparameter selection of mouse testis cells. Proc Natl Acad Sci USA 2000; 97: 8346-51.

23 Giuili G, Tomljenovic A, Labrecque N, Oulad-Abdelghani M, Rassoulzadegan M et al. Murine spermatogonial stem cells: targeted transgene expression and purification in an active state. EMBO Rep 2002; 3: 753-9.

24 Shinohara T, Avarbock MR, Brinster RL. Functional analysis of spermatogonial stem cells in Steel and cryptorchid infertile mouse models. Dev Biol 2000; 220: 401-11.

25 Lo KC, Brugh VM 3rd, Parker M, Lamb DJ. Isolation and enrichment of murine spermatogonial stem cells using rhodamine 123 mitochondrial dye. Biol Reprod 2005; 72: 767-71

26 Honaramooz A, Snedaker A, Boiani M, Scholer H, Dobrinski I et al. Sperm from neonatal mammalian testes grafted in mice. Nature 2002; 418: 778-81.

27 Schlatt S, Honaramooz A, Boiani M, Scholer HR, Dobrinski I. Progeny from sperm obtained after ectopic grafting of neonatal mouse testes. Biol Reprod 2003; 68: 2331-5.

28 Schlatt S, Kim SS, Gosden R. Spermatogenesis and steroidogenesis in mouse, hamster and monkey testicular tissue after cryopreservation and heterotopic grafting to castrated hosts. Reproduction 2002; 124: 339-46.

29 Shinohara T, Inoue K, Ogonuki N, Kanatsu-Shinohara M, Miki H et al. Birth of offspring following transplantation of cryopreserved immature testicular pieces and in-vitro microinsemination. Hum Reprod 2002; 17: 3039-45.

30 Honaramooz A, Megee SO, Dobrinski I. Germ cell transplantation in pigs. Biol Reprod 2002; 66: 21-8.

31 Dobrinski I, Megee S, Honaramooz A. Xenografting of testis tissue from neonatal ram lambs into mouse hosts accelerates testicular maturation and sperm production. Biol Reprod 2003; 68 (Suppl 1): 190.

32 Oatley JM, Reeves JJ, McLean DJ. Biological activity of cryopreserved bovine spermatogonial stem cells during in vitro culture. Biol Reprod 2004; 71: 942-7.

33 Rathi R, Honaramooz A, Zeng W, Schlatt S, Dobrinski I. Germ cell fate and seminiferous tubule development in bovine testis xenografts. Reproduction 2005; 130: 923-9.

34 Snedaker AK, Honaramooz A, Dobrinski I. A game of cat and mouse: xenografting of testis tissue from domestic kittens results in complete cat spermatogenesis in a mouse host. J Androl 2004; 25: 926-30.

35 Rathi R, Honaramooz A, Zeng W, Turner R, Dobrinski I. Germ cell development in equine testis tissue xenografted into mice. Reproduction 2006; 131: 1091-8.

36 Honaramooz A, Li MW, Penedo MC, Meyers S, Dobrinski I. Accelerated maturation of primate testis by xenografting into mice. Biol Reprod 2004; 70: 1500-3.

37 Schlatt S, Honaramooz A, Ehmcke J, Goebell PJ, Rübben $\mathrm{H}$ et al. Limited survival of adult human testicular tissue as ectopic xenograft. Hum Reprod 2006; 21: 384-9.

38 Arregui L, Rathi R, Zeng W, Honaramooz A, Gomendio M et al. Xenografting of adult mammalian testis tissue. Anim Reprod Sci 2008; 106: 65-76.

$39 \mathrm{Yu}$ J, Cai ZM, Wan HJ, Zhang FT, Ye J et al. Development of neonatal mouse and fetal human testicular tissue as ectopic grafts in immunodeficient mice. Asian J Androl 2006; 8: 393-403.

40 Sato Y, Nozawa S, Yoshiike M, Arai M, Sasaki C et al. Xenografting of testicular tissue from an infant human donor results in accelerated testicular maturation. Hum Reprod 2010 25: 1113-22

41 Wyns C, van Langendonckt A, Wese FX, Donnez J, Curaba M. Long-term spermatogonial survival in cryopreserved and xenografted immature human testicular tissue. Hum Reprod 2008; 23: 2402-14.

42 Lo KC, Yildiz C, Mullen JB, Soosaipillai A, Diamandis EP et al. Long term survival and differentiation of human fetal testes in a xenotransplantation model. Human Reprod 2008; 23 (Suppl 1): i82-5.

43 Goldschmidt R. Some experiments on spermatogenesis in vitro. Proc Natl Acad Sci USA 1915; 1 : 220-2.
44 Champy C. Quelques résultats de la méthode de culture des tissus. Arch Zool Exp Gen 1920; 60: 461-500.

45 Michailow M. Experimentell-histologische untersuchungen über die elemente der hodenkanälchen. Z Zellforsch 1937; 26: 174-201.

46 Stukenborg JB, Schlatt S, Simoni M, Yeung CH, Elhija MA et al. New horizons for in vitro spermatogenesis? An update on novel three-dimensional culture systems as tools for meiotic and post-meiotic differentiation of testicular germ cells. Mol Hum Reprod 2009; 15: 521-9.

47 Sato T, Katagiri K, Gohbara A, Inoue K, Ogonuki N et al. In vitro production of functional sperm in cultured neonatal mouse testes. Nature 2011; 471: 504-7.

48 Menezo YJ, Guerin JF, Czyba JC. Improvement of human early embryo development in vitro by coculture on monolayers of Vero cells. Biol Reprod 1990; 42: 301-6.

49 Cremades N, Bernabeu R, Barros A, Sousa M. In-vitro maturation of round spermatids using co-culture on Vero cells. Hum Reprod 1999; 14: 1287-93.

50 Schlegel PN. Testicular sperm extraction: microdissection improves sperm yield with minimal tissue excision. Hum Reprod 1999; 14: 131-5.

51 Tanaka A, Nagayoshi M, Awata S, Mawatari Y, Tanaka I et al. Completion of meiosis in human primary spermatocytes through in vitro coculture with Vero cells. Fertil Steril 2003; 79 (Suppl 1): 795-801.

52 Heller $\mathrm{CH}$, Clermont Y. Kinetics of the germinal epithelium in man. Recent Prog Horm Res 1964; 20: 545-75.

53 Toyooka Y, Tsunekawa N, Akasu R, Noce T. Embryonic stem cells can form germ cells in vitro. Proc Natl Acad Sci USA 2003; 100: 11457-62.

54 Geijsen N, Horoschak M, Kim K, Gribnau J, Eggan K et al. Derivation of embryonic germ cells and male gametes from embryonic stem cells. Nature 2004; 427: 148-54.

55 Nayernia K, Nolte J, Michelmann HW, Lee JH, Rathsack K et al. In vitro-differentiated embryonic stem cells give rise to male gametes that can generate offspring mice. Dev Cell 2006; 11: 125-32.

56 Clark AT, Bodnar MS, Fox M, Rodriquez RT, Abeyta MJ et al. Spontaneous differentiation of germ cells from human embryonic stem cells in vitro. Hum $\mathrm{Mol}$ Genet 2004; 13: 727-39.

57 Aflatoonian B, Moore H. Human primordial germ cells and embryonic germ cells, and their use in cell therapy. Curr Opin Biotechnol 2005; 16: 530-5.

58 Kee K, Gonsalves JM, Clark AT, Pera RA. Bone morphogenetic proteins induce germ cell differentiation from human embryonic stem cells. Stem Cells Dev 2006; 15: 831-7.

59 Tilgner K, Atkinson SP, Golebiewska A, Stojkovic M, Lako M et al. Isolation of primordial germ cells from differentiating human embryonic stem cells. Stem Cells 2008; 26: 3075-85.

60 West FD, Machacek DW, Boyd NL, Pandiyan K, Robbins KR et al. Enrichment and differentiation of human germ-like cells mediated by feeder cells and basic fibroblast growth factor signaling. Stem Cells 2008; 26: 2768-76.

61 Park TS, Galic Z, Conway AE, Lindgren A, van Handel BJ et al. Derivation of primordial germ cells from human embryonic and induced pluripotent stem cells is significantly improved by coculture with human fetal gonadal cells. Stem Cells 2009; 27: 783-95.

62 Moore H, Aflatoonian B. From stem cells to spermatozoa and back. Soc Reprod Fertil Supp/ 2007; 65: 19-32.

63 Lo KC, Chuang WW, Lamb DJ. Stem cell research: the facts, the myths and the promises. J Urol 2003; 170 (6 Pt 1): 2453-8.

64 Okita K, Ichisaka T, Yamanaka S. Generation of germline-competent induced pluripotent stem cells. Nature 2007; 448: 313-7.

65 Woltjen K, Michael IP, Mohseni P, Desai R, Mileikovsky M et al. piggyBac transposition reprograms fibroblasts to induced pluripotent stem cells. Nature 2009; 458: 766-70.

66 Yamanaka S, Blau HM. Nuclear reprogramming to a pluripotent state by three approaches. Nature 2010; 465: 704-12.

67 Takahashi K, Tanabe K, Ohnuki M, Narita M, Ichisaka T et al. Induction of pluripotent stem cells from adult human fibroblasts by defined factors. Cell 2007; 131: 861-72.

68 Park IH, Zhao R, West JA, Yabuuchi A, Huo H et al. Reprogramming of human somatic cells to pluripotency with defined factors. Nature 2008; 451: 141-6.

69 Clark AT. Egg-citing advances in generating primordial germ cells in the laboratory. Biol Reprod 2010; 82: 233-4.

70 Laurent LC, Ulitsky I, Slavin I, Tran H, Schork A et al. Dynamic changes in the copy number of pluripotency and cell proliferation genes in human ESCs and iPSCs during reprogramming and time in culture. Cell Stem Cell 2011; 8: 106-18.

71 Hussein SM, Batada NN, Vuoristo S, Ching RW, Autio R et al. Copy number variation and selection during reprogramming to pluripotency. Nature $2011 ; 471$ : 58-62.

72 Lister R, Pelizzola M, Kida YS, Hawkins RD, Nery JR et al. Hotspots of aberrant epigenomic reprogramming in human induced pluripotent stem cells. Nature 2011; 471: 68-73 